\title{
Pengaruh Rasio Aktivitas Terhadap Harga Saham Pada Perusahaan Telekomunikasi di Bursa Efek Indonesia
}

\author{
ARGO PUTRA PRIMA \\ Universitas Putera Batam \\ Jl. R. Soeprapto Muka Kuning - Batam Telp. (0778) 7001000 \\ E-mail : argoupb@gmail.com
}

\begin{abstract}
The purpose of this study is to determine the financial performance of the telecommunication companies. The development of the telecommunication in current global era is accelerating a long with the rapid pace of information technology. On the other hand, telecommunication information transfer is expected to able to develop the quality and knowledge of the community. The relationship with the assessment of the financial performance of the telecommunications companies, the level of health of the company for shareholders is very important to know the true condition of a company. Measurement of company financial performance is needed to determine success in achieving these goals. By using financial ratio analysis methods including activity ratios and stock prices. Measurement of financial performance statements is mostly done by using performance measurement tool that are sometimes different. One way to find out the financial performance of a company can be done by analyzing its financial statements. The object in this study is a telecommunication company registered on the Indonesia stock exchange. As for the result of this study, the variable average age of account receivable and inventory turnover variables do not significantly influence stock price. While the total fixed assets turnover variable has a significant effect on stock prices.
\end{abstract}

Keywords: financial performance

Teknologi memudahkan aktivitas manusia dalam berkomunikasi dan mampu menghemat biaya. Kemajuan teknologi saat ini tidak lagi memisahkan antara teknologi informasi dan komunikasi.

Bisnis pertelekomunikasian merupakan bisnis yang dinamik, menarik, multi aspek dan pelopor dalam ekspansi global. Di sisi lain berbagai bukti empirik secara tak langsung telah membuktikan bahwa sektor telekomunikasi merupakan sektor bisnis yang paling diminati oleh perusahaan multi nasional dalam kerangka ekspansi dan globalisasinya Ini terjadi baik dalam rangka swastanisasi maupun dalam konteks aliansi strategis antar pelaku di Negara maju maupun dalam ekspansi ke negara berkembang. Berdasarkan kebijakan pemerintah struktur pasar jasa telekomunikasi sudah diatur sedemikian rupa sehingga perusahaan-perusahaan yang akan masuk dalam industri ini akan mengalami kesulitan.
Setiap perusahaan bertujuan untuk memaksimalkan kekayaan pemegang sahamnya. Pengukuran kinerja keuangan perusahaan diperlukan untuk menentukan keberhasilan dalam dalam mencapai tujuan tersebut. Pengukuran kinerja keuangan berdasarkan laporan keuangan banyak dilakukan dengan menggunakan alat ukur kinerja yang kadang berbeda. Untuk menilai berapa jauh efektivitas operasi perusahaan dalam mencapai tujuannya diperlukan metode pengukuran tertentu. Salah satu cara untuk mengetahui kinerja keuangan suatu perusahaan dapat dilakukan dengan melakukan analisis terhadap laporan keuangannya. Apabila memang pengaruh dari analisis rasio keuangan ini signifikan terhadap pendapatan saham perusahaan, maka sudah bisa dipastikan bahwa dengan menganalisa rasio keuangan perusahaan kita sudah bisa menentukan di perusahaan mana kita harus berinvestasi. Rasio yang 
akan menjadi fokus dalam penelitian ini adalah rasio aktivitas.

Berdasarkan latar belakang diatas, peneliti merumuskan masalah yaitu: Bagaimana pengaruh rata-rata umur piutang perusahaan telekomunikasi terhadap harga saham?; Bagaimanaa pengaruh perputaran persediaan perusahaan telekomunikasi terhadap harga saham?; Bagaimana pengaruh perputaran total aktiva perusahaan telekomunikasi terhadap harga saham?; Bagaimana pengaruh perputaran aktiva tetap perusahaan

Rasio aktivitas adalah rasio yang mengukur seberapa efektif perusahaan dalam memanfaatkan semua sumber daya yang ada padanya. Semua rasio aktivitas ini melibatkan perbandingan antara tingkat penjualan dan investasi pada berbagai jenis aktiva. Rasio-rasio aktivitas menganggap bahwa sebaiknya terdapat keseimbangan yang layak antara penjualan dan beragam unsur aktiva misalnya persediaan, aktiva tetap dan aktiva lainnya. Aktiva yang rendah pada tingkat penjualan tertentu akan mengakibatkan semakin besarnya dana kelebihan yang tertanam pada aktiva tersebut. Dana kelebihan tersebut akan lebih baik bila ditanamkan pada aktiva lain yang lebih produktif. Yang termasuk ke dalam rasio aktivitas adalah sebagai berikut:

1. Rata-rata Umur Piutang adalah rasio yang mengukur efisiensi pengolahan piutang perusahaan, serta menunjukkan berapa lama waktu yang diperlukan untuk melunasi piutang atau merubah piutang menjadi kas Rata-rata piutang ini dapat dirumuskan sebagai berikut :

2. Rasio Perputaran Persediaan (inventory turnover) menunjukkan kemampuan dana yang tertanam dalam inventory berputar dalam suatu periode tertentu, atau likuiditas dari inventory dan tendensi untuk adanya overstock (Riyanto, 2008: 334). Rasio perputaran persediaan mengukur efisiensi pengelolaan persediaan barang dagang. Rasio ini merupakan indikasi yang cukup popular untuk menilai efisiensi operasional, yang memperlihatkan seberapa baiknya manajemen mengontrol modal yang ada pada persediaan.

3. Rasio Perputaran Aktiva Tetap (fixed assets turnover) $\mathrm{i}$ merupakan perbandingan antara penjualan dengan aktiva tetap.Fixed assets turn over mengukur efektivitas penggunaan dana yang tertanam pada harta tetap seperti pabrik dan peralatan, dalam rangka menghasilkan penjualan, atau berapa rupiah penjualan bersih yang dihasilkan oleh setiap rupiah yang diinvestasikan pada aktiva tetap (Sawir, 2003:17).

4. Total Perputaran Aktiva (Total Assets Turn Over) merupakan perbandingan antara penjualan dengan total aktiva suatu perusahaan dimana rasio ini menggambarkan kecepatan perputarannya total aktiva dalam satu periode tertentu.Total assets turn over merupakan rasio yang menunjukkan tingkat efisiensi penggunaan keseluruhan aktiva perusahaan dalam menghasilkan volume penjualan tertentu (Syamsuddin, 2009:19).

Saham sebagai tanda penyertaan atau kepemilikan seseorang atau badan dalam suatu perusahaan atau perseroan terbatas. Wujud saham adalah selembar kertas yang menerangkan bahwa pemilik kertas tersebut adalah pemilik perusahaan yang menerbitkan surat berharga tersebut. Porsi kepemilikan ditentukan oleh seberapa besar penyertaan yang ditanamkan di perusahaan tersebut. Pengertian saham menurut Martono dan Harjito (2006: 367) adalah: "Surat bukti atau tanda kepemilikan bagian modal pada suatu perusahaan. saham adalah: 
"Sertifikat yang menunjukkan bukti kepemilikan suatu perusahaan pemegang saham memiliki klaim atas penghasilan dan aktiva perusahaan. Rasio ini bertujuan untuk mengukur kemampuan perusahaan dalam menghasilkan laba. Menurut Husnan dan Pudjiastuti (2008: 74), rasio harga saham yaitu, margin laba atas penjualan,

Penelitian yang dilakukan oleh Meythi (2011) Dosen Pendidikan Program Profesi Akuntansi Universitas Kristen Maranatha yang berjudul "Pengaruh Likuiditas Dan Profitabilitas Terhadap Harga Saham Perusahaan Manufaktur Yang Terdaftar Di Bursa Efek Indonesia". Variabel yang digunakan dalam studi ini adalah Current Ratio sebagai proksi untuk Laba iklan likuiditas Per Share sebagai proxy untuk profitabilitas. Moderated Regression Analisis digunakan sebagai metode analisis data.

Penelitian yang dilakukan oleh Stefanus Antara (2011) Fakultas Ekonomi dan Bisnis, Jurusan Manajemen Universitas Samratulangi Manado yang berjudul "Analisis Rasio Likuiditas, Aktivitas, Dan Profitabilitas Terhadap Return Saham Perusahaan Wholesale Yang Terdaftar Di Bursa Efek Indonesia". Hasil penelitian menunjukanreturn on equity berpengaruh positif dan signifikan terhadap return saham, sementara current ratio dan assets turnover berpengaruh negatif terhadap return saham.sebaiknya manajemen perusahaan memperhatikan aspek likuiditas dan perputaran aset sehingga peningkatan kinerja dari kedua variabel tersebut akan meningkatkan return saham perusahaan.

Penelitian yang dilakukan oleh Diah Natalisa (2013) Fakultas Ekonomi dan Bisnis, Jurusan Manajemen Universitas Samratulangi Manado yang berjudul "Analisis Pengaruh Rasio Lancar, Rasio Perputaran Total Aktiva, Debt to Equity Ratio, Return on Equity, dan Earning per Share Terhadap Return Saham Perusahaan Sektor Infrastruktur, Utilitas, dan Transportasi yang Terdaftar di Bursa Efek Indonesia" . Berdasarkan hasil uji t, rasio lancar, rasio perputaran total aktiva, debt to equity ratio, dan earning per share tidak berpengaruh terhadap return saham. Return on equity berpengaruh positif dan signifikan terhadap return saham. Berdasarkan uji $\mathrm{F}$, secara simultan atau bersama-sama rasio lancar, rasio perputaran total aktiva, debt to equity ratio, return on equity, dan earning per share tidak berpengaruh terhadap return saham.

\section{METODE}

Penelitian ini dilaksanakan di Bursa Efek Indonesia (BEI) Komplek Mahkota Raya Blok A No.11 Batam Center Telepon (0778) 7483348.

Menurut Arikunto (2006: 130), “ populasi adalah keseluruhan objek penelitian". Populasi dalam penelitian ini adalah perusahaan-perusahaan telekomunikasi yang terdaftar di Bursa Efek Indonesia selama periode 2009 - 2013. Populasi perusahaan telekomunikasi berjumlah 9 perusahaan. Menurut Arikunto (2006: 131), “ sampel adalah sebagian atau wakil populasi yang diteliti ". Teknik pengambilan sampel yang digunakan dalam penelitian ini adalah purposive sampling yaitu sampel yang dipilih berdasarkan atas adanya tujuan dan pertimbangan tertentu.

Pengambilan sampel yang digunakan adalah pada semua perusahaan telekomunikasi yang ada sesuai dengan populasi. Alasan penulis dalam pengambilan sampel dalam penelitian ini adalah:

1. Perusahaan tersebut memiliki data yang lengkap sesuai dengan variabel yang diteliti dalam penelitian ini, dan mudah dalam pencarian data bagi peneliti.

2. PT. Telekomunikasi Indonesia Tbk dan PT. Indosat Tbk merupakan perusahaan telekomunikasi yang tergolong LQ 45. Oleh karena itu peneliti ingin mengetahui kinerja keuangan perusahaan tersebut. 
Tabel 1 Daftar sampel perusahaan telekomunikasi di BEI

\begin{tabular}{|l|l|l|}
\hline NO & Kode & Nama Perusahaan \\
\hline 1 & BTEL & PT. Bakrie Telcom Tbk \\
\hline 2 & EXCL & $\begin{array}{l}\text { PT. Excelcomindo } \\
\text { Pratama Tbk }\end{array}$ \\
\hline 3 & ISAT & PT. Indosat Tbk \\
\hline 4 & FREN & PT Smartfren Tbk \\
\hline 5 & INVS & $\begin{array}{l}\text { PT. Inovisi Infracom } \\
\text { Tbk }\end{array}$ \\
\hline 6 & TLKM & $\begin{array}{l}\text { PT. Telekomunikasi } \\
\text { Indonesia Tbk }\end{array}$ \\
\hline 7 & TBIG & $\begin{array}{l}\text { PT. Tower Bersama } \\
\text { Infrastructure. Tbk }\end{array}$ \\
\hline 8 & TRIO & $\begin{array}{l}\text { PT. Trikomsel Oke. } \\
\text { Tbk }\end{array}$ \\
\hline
\end{tabular}

Sumber : www.idx.co.id

Dalam penelitian ini terdiri dari 5 (empat) variabel yaitu:

1. Variabel Independen (X):

a. (X1) Adalah Rata-rata Umur Piutang.

b. (X2) Adalah Perputaran Persediaan.

c. (X3) Adalah Perputaran Total Aktiva .

d. (X4) Adalah Perputaran Aktiva Tetap.

2. Variabel Dependen (Y) merupakan variabel terikat di penelitian adalah Harga saham perusahaan telekomunikasi di Bursa Efek Indonesia (BEI).

Uji normalitas ini bertujuan untuk menguji apakah dalam model regresi, variabel bebas dan variabel terikat keduanya memiliki distribusi normal atau tidak. Model regresi yang baik adalah memiliki data berdistribusi normal. Untuk menguji apakah terdapat distribusi yang normal atau tidak dalam model regresi maka digunakanlah uji Kolmogorof Smirnov dan analisis grafik (Ghozali, 2011: 160).

Nilai tolerance mengukur variabilitas variabel independen yang terpilih yang tidak dijelaskan oleh variabel independen lainnya. Nilai cut off yang umum dipakai unttuk menunjukan adanya multikolinearitas adalah nilai tolerance $<0,10$ atau sama dengan nilai
VIF > 10. Multikolinearitas juga dapat dideteksi dengan menganalisis matriks korelasi variabel independen.

Dasar analisis grafik scatterplot adalah jika ada pola tertentu, seperti titiktitik yang membentuk pola tertentu yang teratur (bergelombang, melebar kemudian menyempit), maka mengindikasikan telah terjadi heteroskedastisitas. Jika tidak ada pola yang jelas, serta titik-titik menyebar di atas dan di bawah angka) pada sumbu Y, maka tidak terjadi heteroskedastisitas (Ghozali, 2011:139).

Uji autokorelasi bertujuan menguji apakah dalam model regresi linier ada korelasi antara kesalahan pengganggu pada periode $\mathrm{t}$ dengan kesalahan pengganggu pada periode t-1 (sebelumnya). Cara untuk mendeteksi adanya autokorelasi adalah dengan menggunakan uji Lagrange Multiplier (LM test) yang akan menghasilkan statistik Breusch-Godfrey. Uji LM digunakan untuk sampel besar 100 observasi dan lebih tepat digunakan dibandingkan uji Durbin-Watson (Ghozali, 2011: 113).

Analisis regresi linear berganda adalah hubungan secara linear antara dua atau lebih variable independen $\left(\mathrm{X}_{1}, \mathrm{X}_{2}, \ldots, \mathrm{X}_{\mathrm{n}}\right)$ dengan variabel dependen (Y). Data yang digunakan biasanya berskala interval atau rasio. Persamaan regresi linear berganda sebagai berikut Sugiyono (2012: 275) :

$\mathrm{Y}=\alpha+\mathrm{b}_{1} \mathrm{X}_{1}+\mathrm{b}_{2} \mathrm{X}_{2}+\ldots+\mathrm{b}_{\mathrm{n}} \mathrm{X}_{\mathrm{n}}$

Keterangan :

$\mathrm{Y}=$ Variabel dependen ( nilai yang di prediksikan )

$\mathrm{X} 1$ dan $\mathrm{X} 2=$ variabel independen

$\mathrm{a}=$ konstanta

$\mathrm{b} \quad=$ koefisien regresi ( nilai peningkatan atau penurunan )

Untuk menguji hipotesis yang telah ditentukan maka teknik analisis yang digunakan adalah analisis regresi linier berganda (multiple regression). Dengan menggunakan berikut : Pengujian Dengan Koefisien Regresi Parsial (uji t); Pengujian Terhadap Koefisien Regresi Secara Silmutan (Uji F) 


\section{HASIL}

4.1 Uji Asumsi Klasik

Uji Normalitas

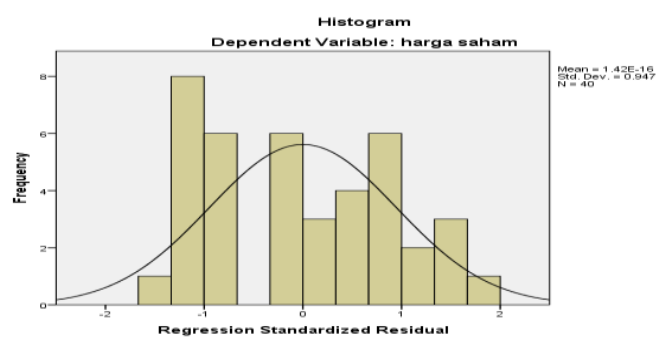

Sumber : Olahan SPSS V.21

Gambar 2 Histogram

Dari hasil output di atas, dapat disimpulkan bahwa model pada penelitian ini memiliki distribusi normal. hal tersebut dapat dilihat dari bentuk kurva yang menyerupai lonceng atau bell shaped.

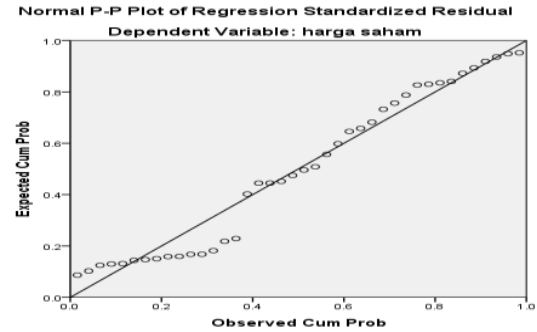

Sumber : Olahan SPSS V.21

Gambar 3 Normal P-P Plot of regression Standardized Residual

Dengan melihat hasil uji pada diagram Normal P-P Plot Regression Standardized, maka dapat ditarik kesimpulan bahwa pada model ini memiliki distribusi normal, hal tersebut dapat dilihat dari titik yang berada pada sekitar garis diagonal.

\section{Uji Multikolineritas}

$$
\text { Hasil pengujian terhadap }
$$

multikolinearitas pada penelitian ini dapat dilihat pada table 4.2 :

Tabel 2 Coefficients ${ }^{\mathrm{a}}$

a. Dependent variabel : harga saham

\begin{tabular}{|c|c|c|c|c|c|c|c|}
\hline \multirow[t]{2}{*}{ Model } & \multicolumn{2}{|c|}{$\begin{array}{l}\text { Unstandardized } \\
\text { Coefficients }\end{array}$} & \multirow{2}{*}{$\begin{array}{l}\text { Standardized } \\
\text { Coefficients } \\
\text { Beta }\end{array}$} & \multirow[t]{2}{*}{ T } & \multirow[t]{2}{*}{ Sig. } & \multicolumn{2}{|l|}{$\begin{array}{l}\text { Collinearity } \\
\text { Statistics }\end{array}$} \\
\hline & $B$ & Std. Error & & & & Tolerance & VIF \\
\hline $\begin{array}{ll}\text { (Constant) } & \\
\text { rata-rata } \\
\text { piutang }\end{array}$ & $\begin{array}{l}2442.215 \\
.725\end{array}$ & $\begin{array}{l}912.746 \\
7.340\end{array}$ & .016 & $\begin{array}{l}2.676 \\
.099\end{array}$ & $\begin{array}{l}.011 \\
.922\end{array}$ & .889 & 1.125 \\
\hline $\begin{array}{l}\text { perputaran } \\
\text { lpersedian }\end{array}$ & .364 & & & .108 & .915 & & \\
\hline $\begin{array}{l}\text { perputaran aktiva } \\
\text { tetap }\end{array}$ & -88.180 & 33.894 & -.972 & 2.602 & .01 & 165 & 6.069 \\
\hline $\begin{array}{l}\text { perputaran total } \\
\text { aktiva }\end{array}$ & 3595.870 & 1711.194 & .754 & 2.101 & .043 & .179 & 5.592 \\
\hline
\end{tabular}

Sumber : Olahan SPSS V.21

Berdasarkan table 2 di atas dapat dilihat bahwa tidak ada satupun variable bebas yang memiliki nilai VIF lebih dari 10 dan tidak ada yang memiliki tolerance value lebih kecil dari 0.1. Jadi dapat disimpulkan bahwa penelitian ini bebas dari adanya multikolinearitas. Dari hasil analisis, didapat nilai VIF untuk variabel rata-rata umur piutang adalah $1.125(<10)$ dan nilai tolerance sebesar $0.889(>0,1)$, nilai VIF untuk variabel perputaran persediaan adalah $1.371(<10)$ dan nilai tolerance sebesar $0.729(>0.1)$, nilai VIF untuk perputaran aktiva tetap adalah 6.069 $(<10)$ dan nilai tolerance sebesar 0.165 $(>0.1)$, nilai VIF untuk perputaran total aktiva adalah $5.592 \quad(<10)$ dan nilai tolerance sebesar $0.179(>0.1)$. Dari hasil ini maka dapat disimpulkan bahwa semua variabel bebas yang dipakai dalam penelitian ini lolos uji gejala multikolinearitas.

Uji Heteroskedastisitas

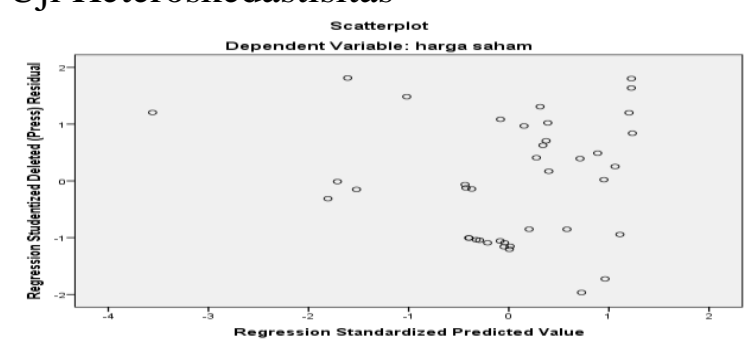

Sumber : Olahan SPSS V.21

Gambar 4 Scatterplot

Pada gambar 4.3 tentang grafik scatterplot di atas terlihat titik-titik menyebar secara acak tidak membentuk sebuah pola tertentu serta tersebar baik di atas maupun di bawah angka 0 pada sumbu $Y$. Hal ini dapat disimpulkan bahwa tidak terjadi heteroskedastisitas pada model regresi, sehingga model regresi layak dipakai untuk melihat pengaruh variabel independen terhadap variabel dependen.

Uji Autokorelasi

Berikut merupakan hasil uji autokorelasi : Tabel 3 Model Summary ${ }^{\mathrm{b}}$

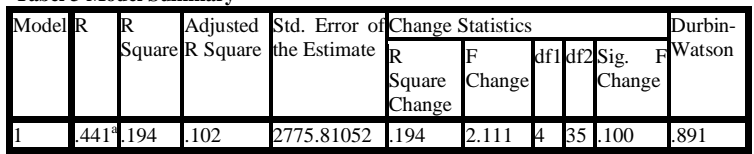

a. Predictors: (Constant), perputaran total aktiva, rata-rata umur piutang, perputaran persedian, perputaran aktiva tetap

b. Dependent Variable: harga saham 
Tabel 3 memperlihatkan nilai statistik D-W sebesar 0.891 dimana nilai ini terletak diantara -2 dan +2 , dari pengamatan ini dapat disimpulkan bahwa tidak terjadi autokorelasi positif maupun autokorelasi negatif dalam penelitian ini.

\section{Uji Hipotesis}

Uji F

Uji $F$ digunakan untuk menguji adanya pengaruh variabel independen secara simultan terhadap variabel dependen yaitu profit margin dan total assets turnover terhadap tingkat rentabilitas ekonomi perusahaan.

Variabel independen dikatakan memiliki pengaruh secara simultan terhadap variabel dependen jika $F_{\text {hitung }} \geq F_{\text {tabel }}$ dan signifikansi $<\alpha$.

Pengujian ini memiliki kriteria sebagai berikut :

a. Taraf uji signifikansi $(a)=0,05$

b. Degree offreedom (Df)

Df $_{1}=$ Jumlah variabel $-1=5-1=4$

$\mathrm{Df}_{2}=\mathrm{n}-$ jumlah variabel $=40-5=35$

c. Nilai $F_{\text {tabel }}=2,64$

Berikut merupakan hasil uji $\mathrm{F}$ :

\begin{tabular}{|c|c|c|c|c|c|}
\hline \multirow{2}{*}{\multicolumn{6}{|c|}{ Tabel 4 ANOVA $^{\mathrm{a}}$}} \\
\hline & & & & & Sig. \\
\hline |Regression & 65058333.936 & 4 & 16264583.484 & 2.111 & $100^{\mathrm{b}}$ \\
\hline 1 Residual & 269679341.439 & 35 & 7705124.041 & & \\
\hline Total & 334737675.375 & 39 & & & \\
\hline
\end{tabular}

Hipotesis pengujian ini adalah ratarata umur piutang, perputaran persediaan, perputaraan aktiva tetap, dan perputaran total aktiva tidak berpengaruh signifikan secara simultan terhadap harga saham.

Dari hasil perhitungan pada uji $\mathrm{F}$ menunjukkan bahwa $F_{\text {hitung }}<\mathrm{F}_{\text {tabel }}$, yaitu sebesar $2,111<2,64$ dengan nilai signifikan $0,100>0,05$. Maka dapat dinyatakan bahwa hipotesis adalah Ha ditolak dan Ho diterima, dengan ini dapat disimpulkan bahwa rata-rata umur piutang, perputaran persediaan, perputaraan aktiva tetap, dan perputaran total aktiva tidak memiliki pengaruh signifikan secara simultan terhadap harga saham.

Uji Parsial (Uji t/ T-Test)

Uji ini dilakukan untuk melihat pengaruh variabel independen terhadap variabel dependen secara parsial.

Variabel independen dikatakan memiliki pengaruh terhadap variabel dependen jika nilai $t_{\text {hitung }} \geq t_{\text {tabel }}$ dan signifikansi $<\alpha$. Dalam hal ini adalah untuk menguji pengaruh profit margin $\left(\mathrm{X}_{1}\right)$ dan total assets turnover $\left(\mathrm{X}_{2}\right)$ terhadap tingkat rentabilitas ekonomi perusahaan $(\mathrm{Y})$.

Pengujian ini memiliki kriteria sebagai berikut :

a. Taraf uji signifikan $(a)=0,05$

b. Degree of freedom (Df) $=\mathrm{n}-\mathrm{k}=40$ $5=35$

c. Nilai $t_{\text {tabel }} 2$ sisi, $\alpha=0,05: 2=$ 0,025 , didapat $t_{\text {tabel }}=2,030$

Berikut adalah hasil uji $\mathrm{t}$ :

Tabel 5 Coefficients ${ }^{\mathrm{a}}$

\begin{tabular}{|c|c|c|c|c|c|}
\hline \multirow[t]{2}{*}{ Model } & \multicolumn{2}{|c|}{$\begin{array}{l}\text { Unstandardized } \\
\text { Coefficients }\end{array}$} & \multirow{2}{*}{\begin{tabular}{|l} 
Standardized \\
Coefficients \\
Beta
\end{tabular}} & \multirow[t]{2}{*}{$\mathrm{T}$} & \multirow[t]{2}{*}{ Sig. } \\
\hline & \begin{tabular}{|l} 
Coefficie \\
B
\end{tabular} & Std. Error & & & \\
\hline (Constant) & 2442.215 & 912.746 & & 2.676 & .011 \\
\hline $\begin{array}{ll}\begin{array}{l}\text { rata-rata } \\
\text { piutang }\end{array} & \text { umur } \\
\end{array}$ & 7.725 & 7.340 & .016 & .099 & .922 \\
\hline perputaran persedian & .364 & 3.365 & .019 & -.108 & .915 \\
\hline $\begin{array}{l}\text { perputaran aktiva } \\
\text { tetap }\end{array}$ & a- 88.180 & 33.894 & .972 & 2.602 & .014 \\
\hline $\begin{array}{l}\text { perputaran total } \\
\text { aktiva }\end{array}$ & 13595.870 & 1711.194 & 754 & 2.101 & .043 \\
\hline
\end{tabular}
sebagai berikut :

1. Hipotesis pertama $\left(\mathrm{H}_{1}\right)$ adalah ratarata umur piutang tidak berpengaruh signifikan secara parsial terhadap harga saham.

2. Hipotesis kedua $\left(\mathrm{H}_{2}\right)$ adalah perputaran persediaan tidak berpengaruh signifikan secara parsial terhadap harga saham.

3. Hipotesis ketiga $\left(\mathrm{H}_{3}\right)$ adalah perputaran aktiva tetap berpengaruh signifikan dan negatif secara parsial terhadap harga saham.

4. Hipotesis keempat $\left(\mathrm{H}_{4}\right)$ adalah perputaran total aktiva berpengaruh signifikan dan positif secara parsial terhadap harga saham.

\section{PEMBAHASAN}

Dengan menganalisis laporan keuangan tahunan pada perusahaanperusahaan telekomunikasi selama lima tahun yaitu tahun 2009-2013, penulis ingin mengetahui seberapa besar analisis laporan keuangan mempengaruhi kinerja 
perusahaan. Sebagai sampel penelitian, penulis meneliti beberpa perusahaan telekomunikasi yang terdaftar di Bursa Efek Indonesia, diantaranya sebagai berikut :

Pembahasan dalam peneelitian ini adalah sebagai berikut :

Rata-rata umur piutang tidak berpengaruh signifikan secara parsial terhadap harga saham $\left(\mathrm{H}_{1}\right)$.

Berdasarkan output di atas menunjukkan bahwa $t_{\text {hitung }}<t_{\text {tabel, }}$ yaitu sebesar $0,099<$ 2,030 dengan nilai signifikan 0,922>0,05. Maka dapat disimpulkan bahwa pada hipotesis pertama $\mathrm{Ha}$ ditolak dan $\mathrm{Ho}$ diterima. Dengan kata lain rata-rata umur piutang tidak memiliki pengaruh signifikan secara parsial terhadap tingkat harga saham.

Perputaran persediaan tidak berpengaruh signifikan secara parsial terhadap harga saham $\left(\mathrm{H}_{2}\right)$.

Berdasarkan output di atas menunjukkan bahwa $t_{\text {hitung }}<t_{\text {tabel, }}$ yaitu sebesar $-0,108<$ 2,030 dengan nilai signifikan 0,920>0,05. Maka dapat disimpulkan bahwa pada hipotesis kedua Ha ditolak dan Ho diterima. Dengan kata lain perputaran persediaan tidak memiliki pengaruh signifikan secara parsial terhadap harga saham.

Perputaran aktiva tetap berpengaruh signifikan dan negatif secara parsial terhadap harga saham $\left(\mathrm{H}_{3}\right)$.

Berdasarkan output di atas menunjukkan bahwa $t_{\text {hitung }}<t_{\text {tabel, }}$ yaitu sebesar $-2,602<$ 2,030 dengan nilai signifikan $0,014<0,05$. Maka dapat disimpulkan bahwa pada hipotesis kedua Ha diterima dan Ho ditolak. Dengan kata lain perputaran aktiva tetap memiliki pengaruh signifikan secara parsial terhadap harga saham.

Perputaran total aktiva berpengaruh signifikan dan positif secara parsial terhadap harga saham $\left(\mathrm{H}_{4}\right)$.
Berdasarkan output di atas menunjukkan bahwa $t_{\text {hitung }}>t_{\text {tabel, }}$ yaitu sebesar 2,101 > 2,030 dengan nilai signifikan 0,043 <0,05. Maka dapat disimpulkan bahwa pada hipotesis kedua Ha diterima dan Ho ditolak. Dengan kata lain perputaran total aktiva memiliki pengaruh signifikan secara parsial terhadap harga saham.

Rata-rata umur piutang, perputaran persediaan, perputaran aktiva tetap, dan perputaran total aktiva berpengaruh signifikan secara simultan terhadap harga saham (H5).

Hipotesis pengujian ini adalah rata-rata umur piutang, perputaran persediaan, perputaraan aktiva tetap, dan perputaran total aktiva tidak berpengaruh signifikan secara simultan terhadap harga saham. hal ini dapat dilihat dari hasil perhitungan pada uji $\mathrm{F}$ menunjukkan bahwa $\mathrm{F}_{\text {hitung }}<\mathrm{F}_{\text {tabel }}$, yaitu $2,111<2,64$ dengan nilai signifikan $0,100>0,05$.

\section{SIMPULAN}

Dari hasil pengolahan data yang dilakukan, maka dapat disimpulkan sebagai berikut :

1. Rata-rata umur piutang tidak berpengaruh signifikan secara parsial terhadap harga saham $\left(\mathrm{H}_{1}\right)$ perusahaan telekomunikasi. Hal ini dilihat dari nilai signifikan $0,922>$ 0,05 .

2. Perputaran persediaan tidak berpengaruh signifikan secara parsial terhadap harga saham $\left(\mathrm{H}_{2}\right)$ perusahaam telekomunikasi. Hal ini dilihat dari nilai signifikan $0,920>$ 0,05 .

3. Perputaran aktiva tetap berpengaruh signifikan dan negatif secara parsial terhadap harga saham $\left(\mathrm{H}_{3}\right)$ perusahaan telekomunikasi. Hal ini dilihat dari nilai signifikan $0,014<$ 0,05 .

4. Perputaran total aktiva berpengaruh signifikan dan positif secara parsial terhadap harga saham 
perusahaan telekomunikasi. Hal ini dilihat dari nilai signifikan $0,043<$ 0,05 .

5. Rata-rata umur piutang, perputaran persediaan, perputaran aktiva tetap, dan perputaran total aktiva tidak berpengaruh signifikan secara simultan terhadap harga saham (H5) perusahaan telekomunikasi. Hal ini dilihat dari nilai signifikan $0,100>$ 0,05 .

Dari penelitian yang telah penulis lakukan, maka penulis memberikan saran :

1. Diharapkan kepada perusahaan telekomunikasi yang listing di Bursa Efek Indonesia (BEI) untuk meningkatkan kegiatan operasi perusahaannya dan memperhatikan dengan baik rata-rata umur piutang,perputaran persediaan, perputaran aktiva tetap, dan perputaran total aktiva perusahaan.

2. Sebaiknya perusahaan lebih memperhatikan faktor-faktor lain yang lebih mempengaruhi harga saham perusahaan.

3. Penulis menyarankan pada penelitian selanjutnya untuk dapat memasukkan faktor yang lain selain rata-rata umur piutang, perputaran persediaan, perputaran aktiva tetap, dan perputaran total aktiva (rasio aktivitas perusahaan) yang mempengaruhi harga saham agar penelitian dapat lebih digeneralisasikan. Karena, pada rasio aktivitas secara parsial hanya dua variabel yang berpengaruh signifikan dan secara simultan tidak berpengaruh signifikan.

\section{DAFTAR RUJUKAN}

\begin{tabular}{|c|c|c|}
\hline Djoko & Susanto & Agus \\
\hline & Sabardi.2010."Analisis & Teknikal di \\
\hline & Bursa & Efek"Edisi \\
\hline & $\begin{array}{l}\text { Kedua.Yogyakarta.UPP } \\
\text { YPKN. }\end{array}$ & STIM \\
\hline
\end{tabular}

Diah Natalisa . 2013.ISSN 14124521."Analisis Pengaruh Rasio Lancar, Rasio Perputaran Total Aktiva, Debt to Equity Ratio, Return on Equity, dan Earning per Share Terhadap Return Saham Perusahaan Sektor Infrastruktur, Utilitas, dan Transportasi yang Terdaftar di Bursa Efek Indonesia".

Eko Priyono Pratomo, Ubaidillah Nugraha.2004."Reksadana Solusi Perencanaan Investasi Di Era Modern", Edisi Revisi. PT Gramedia : Jakarta.

Jusuf Anwar.2005.’Pasar Modal Sebagai Sarana Pembiayaan dan Investasi ".Bandung, PT Alumni.

Meythi.2011.ISSN: 1693-8305. "Pengaruh Likuiditas dan Profitabilitas Terhadap Harga Saham Perusahaan Manufaktur yang Terdaftar di Bursa Efek Indonesia".

Pernyataan Standar Akuntansi Keuangan No.10.

Sri Hermuningsih.2012.Pengantar Pasar Modal Indonesia.UPP YPKN:Yogyakarta.

Stefanus Antara.2011.ISSN 2303-1174." Analisis Rasio Likuiditas, Aktivitas, Dan Profitabilitas Terhadap Return Saham Perusahaan Wholesale Yang Terdaftar Di Bursa Efek Indonesia".

Sugiyono, (2011). Metode Penilitian Kuantitatif, Kualitatif dan $R \& D$. Alfabeta. Bandung

Suhartono dan Fadillah Qudsi.2009.”Portofolio Investasi dan Bursa Efek, Pendekatan Teori 
dan Praktek Suplement : Trick dan Kamus Gaul di Pasar Modal",Edisi

Pertama.Yogyakarta, UPP STIM YPKN.

Undang-Undang tentang Pasar Modal No : 8 Tahun 1995.

Wibowo, Agung Edy. (2012). Aplikasi SPSS

Dalam Penelitian. Gava Media.

Yogyakarta

www.idx.co.id 